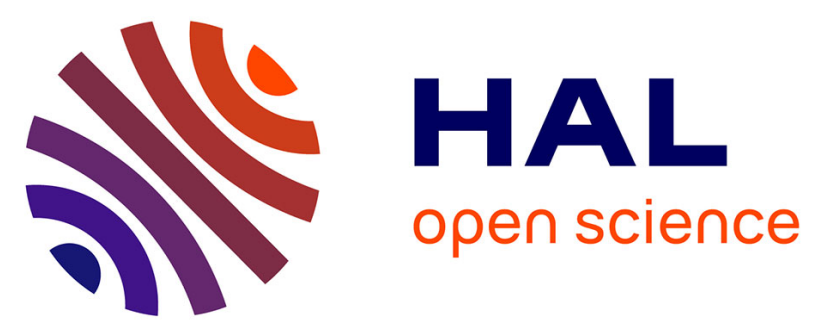

\title{
Projections of regional changes in forest net primary productivity for different tree species in Europe driven by climate change and carbon dioxide
}

Christopher Reyer, Petra Lasch-Born, Felicitas Suckow, Martin Gutsch, Aline Murawski, Tobias Pilz

\section{To cite this version:}

Christopher Reyer, Petra Lasch-Born, Felicitas Suckow, Martin Gutsch, Aline Murawski, et al.. Projections of regional changes in forest net primary productivity for different tree species in Europe driven by climate change and carbon dioxide. Annals of Forest Science, 2014, 71 (2), pp.211 - 225. 10.1007/s13595-013-0306-8 . hal-01098413

\section{HAL Id: hal-01098413 https://hal.science/hal-01098413}

Submitted on 24 Dec 2014

HAL is a multi-disciplinary open access archive for the deposit and dissemination of scientific research documents, whether they are published or not. The documents may come from teaching and research institutions in France or abroad, or from public or private research centers.
L'archive ouverte pluridisciplinaire HAL, est destinée au dépôt et à la diffusion de documents scientifiques de niveau recherche, publiés ou non, émanant des établissements d'enseignement et de recherche français ou étrangers, des laboratoires publics ou privés. 


\title{
Projections of regional changes in forest net primary productivity for different tree species in Europe driven by climate change and carbon dioxide
}

\author{
Christopher Reyer • Petra Lasch-Born • Felicitas Suckow • \\ Martin Gutsch • Aline Murawski • Tobias Pilz \\ Received: 20 September 2012 / Accepted: 28 May 2013 /Published online: 12 June 2013 \\ (C) INRA and Springer-Verlag France 2013
}

\begin{abstract}
- Context Projecting changes in forest productivity in Europe is crucial for adapting forest management to changing environmental conditions.

- Aims The objective of this paper is to project forest productivity changes under different climate change scenarios at a large number of sites in Europe with a stand-scale processbased model.

- Methods We applied the process-based forest growth model 4C at 132 typical forest sites of important European tree species in ten environmental zones using climate change scenarios from three different climate models and two different assumptions about $\mathrm{CO}_{2}$ effects on productivity.

- Results This paper shows that future forest productivity will be affected by climate change and that these effects

\footnotetext{
Handling Editor: Jean Daniel Bontemps

Contribution of the co-authors Christopher Reyer: study design, data preparation, preparation of figures and tables, interpretation and analysis of results, and writing of paper

Petra Lasch-Born: study design, data preparation, model runs, interpretation and analysis of results, and supervision

Felicitas Suckow: data preparation and validation

Martin Gutsch: data preparation

Aline Murawski: data preparation

Tobias Pilz: data preparation and preparation of figures and tables All authors commented on the manuscript.
}

Electronic supplementary material The online version of this article (doi:10.1007/s13595-013-0306-8) contains supplementary material, which is available to authorized users.

C. Reyer $(\varangle) \cdot$ P. Lasch-Born · F. Suckow $\cdot$ M. Gutsch •

A. Murawski $\cdot$ T. Pilz

Potsdam Institute for Climate Impact Research, RD II: Climate Impacts and Vulnerabilities, Telegrafenberg, P.O. Box 601203,

14412 Potsdam, Germany

e-mail: reyer@pik-potsdam.de

C. Reyer

Department of Geography, Humboldt University Berlin, Berlin, Germany depend strongly on the climate scenario used and the persistence of $\mathrm{CO}_{2}$ effects. We find that productivity increases in Northern Europe, increases or decreases in Central Europe, and decreases in Southern Europe. This geographical pattern is mirrored by the responses of the individual tree species. The productivity of Scots pine and Norway spruce, mostly located in central and northern Europe, increases while the productivity of Common beech and oak in southern regions decreases. It is important to note that we consider the physiological response to climate change excluding disturbances or management.

- Conclusions Different climate change scenarios and assumptions about the persistence of $\mathrm{CO}_{2}$ effects lead to uncertain projections of future forest productivity. These uncertainties need to be integrated into forest management planning and adaptation of forest management to climate change using adaptive management frameworks.

Keywords $4 \mathrm{C}$ (FORESEE) $\cdot \mathrm{CO}_{2}$ effects $\cdot$ Environmental change $\cdot$ Level-II plots $\cdot$ Process-based modelling . Uncertainties

\section{Introduction}

Productivity is a key ecological variable for forest management and also highly relevant to understand carbon cycling in forest ecosystems. Ground-based measurements and observations from remote sensing have indicated shifts in forest productivity in past decades (e.g. Boisvenue and Running 2006; Kahle et al. 2008; Kauppi et al. 1992; Myneni et al. 1997; Nemani et al. 2003; Spiecker et al. 1996). In Europe, not only climate change, increasing atmospheric carbon dioxide concentrations $\left[\mathrm{CO}_{2}\right]$, and nitrogen deposition but also land use changes and recovery from past management combined with novel management practices have been highlighted as 
possible causes (Boisvenue and Running 2006; de Vries et al. 2006; Spiecker et al. 1996; Solberg et al. 2009).

Forest management has to adapt to changing environmental conditions to ensure the functions and services forest ecosystems provide to society. Therefore, knowing if, where and with which magnitude past productivity changes will continue or reverse is crucial. Process-based models (PBMs) describe changes in responses to environmental variables based on plant physiology and are thus suitable tools to simulate climate change impacts on forests and to assess adaptive forest management strategies (Chmura et al. 2011; Fontes et al. 2010). Stand-level PBMs simulate processes for typical forest stands and provide detailed physiological and structural output. They require detailed input data for stand and site initialization (Fontes et al. 2010) and for speciesspecific parameters, which are derived from physiological measurements (Landsberg 2003). Thus, they represent local physiological-based responses to environmental change and only seldom integrate processes that occur at the landscape scale such as disturbances (Seidl et al. 2011).

Even without considering disturbances, projections of future forest productivity changes are associated with several types of uncertainties. These uncertainties result from uncertainties in climate change scenarios, model parameters, and model structure. Climate change scenario uncertainty is a combination of uncertainties in projections of future greenhouse gas emissions (and the resulting climate change) and the different climate change trajectories simulated by different climate models using the same forcing. In the case of forest modelling, this is essentially a model input uncertainty. An example for model structural uncertainty is the increasing evidence that effects of carbon dioxide $\left(\mathrm{CO}_{2}\right)$ which are commonly integrated into PBMs are rather a transient phenomenon at the tree and forest stand level. After an initial increase, productivity becomes limited by other factors such as nutrient availability and plants acclimate to elevated $\left[\mathrm{CO}_{2}\right]$ (Körner et al. 2005; Norby et al. 2010). However, there is no full explanation of these effects yet and model formulations accounting for these feedbacks are lacking.

The objective of this paper is to project forest productivity changes at a large number of sites in Europe with one single stand-scale PBM using an ensemble of climate change scenarios and accounting for uncertainties regarding the persistence of $\mathrm{CO}_{2}$ effects. We use international and newly available databases (e.g. ICP Forests Network (de Vries et al. 2003) and European Soil Database (ESBN 2004)) that provide crucial information for studies simulating forest productivity under changing environmental conditions (Bugmann et al. 2010). Furthermore, to account for the uncertainty arising from climate change models as important inputs of forest modelling, we rely on several climate change scenarios from different regional climate models. This approach allows for an identification of expected changes in and uncertainties of forest productivity for the three most important European tree species (Scots pine (Pinus sylvestris L.), Norway spruce (Picea abies L. Karst.), European beech (Fagus sylvatica L.), and a generic oak representing Sessile and Pedunculate oak (Quercus petraea Liebl. and Quercus robur L.) in ten environmental zones in Europe as defined by Metzger et al. (2005). There have already been several studies of future forest productivity in Europe (e.g. Kahle et al. 2008; Kellomäki and Leinonen 2005; Morales et al. 2007; Wamelink et al. 2009), but our methodology complements them in a number of ways: we use a large number of typical, existing forest stands which have a defined age, density, site, and climate and represent the current species composition. We also simulate tree species rather than plant functional types and apply the same model all over Europe which is not common for stand-scale PBMs (e.g. Kellomäki and Leinonen 2005). Finally, we explicitly consider uncertainties of $\mathrm{CO}_{2}$ effects on forest productivity by incorporating different assumptions about the persistence of $\mathrm{CO}_{2}$ effects in our simulations and we do not rely on a single climate change scenario but rather several scenarios.

It is important to note that our analysis does not cover Mediterranean tree species but is restricted to boreal and temperate species that occur in the Mediterranean in higher altitudes. Furthermore we only describe the physiological responses to global change and although considering managed forests, we do not include management or disturbances. Additionally, our typical stands are simulated for 30 years under a broad range of climatic conditions in different future time periods. This approach decouples our stands from concrete temporal predictions but allows us to control long-term ontogenetic effects and to investigate the reaction of European forests to environmental change as if these would maintain their present distribution and ontongenetic stage. All these points highlight that our analysis does not intend to present predictions of the productivity of Europe's forests but rather projections of possible future productivity changes valid under the assumptions made in the modelling chain presented here.

\section{Material and methods}

\subsection{The model 4C}

The model 4C (Forest Ecosystems in a Changing Environment) has been developed to describe forest behaviour under changing environmental conditions (Bugmann et al. 1997; Lasch et al. 2005). It describes processes on tree- and stand-level based on findings from eco-physiological experiments, longterm observations, and physiological modelling. The model includes descriptions of tree species composition, forest structure, leaf area index as well as ecosystem carbon and water 
balances. Establishment, growth, and mortality of tree cohorts are explicitly modelled on a patch on which horizontal homogeneity is assumed. The soil sub-model describes temperature, and water, carbon and nitrogen dynamics in different soil layers. 4C requires daily meteorological variables, annual $\left[\mathrm{CO}_{2}\right]$ as well as a soil and a forest stand description. Currently $4 \mathrm{C}$ is parameterized for 11 tree species, particularly the most abundant tree species of Central Europe, European beech, Norway spruce, Scots pine, Pedunculate and Sessile oak. The latter two are not differentiated in this study but considered as a generic oak parameterization.

The effects of changing environmental conditions are captured in $4 \mathrm{C}$ in the following ways. Elevated $\left[\mathrm{CO}_{2}\right]$ affects productivity in two ways: (1) it increases the internal partial pressure of $\mathrm{CO}_{2}$ which increases light-use efficiency and gross assimilation and (2) it reduces stomatal conductance and the potential transpiration water demand and hence increases wateruse efficiency. There is however no downregulation of photosynthesis under elevated $\left[\mathrm{CO}_{2}\right]$. Water stress (described in more detail in Reyer et al. (2010)) and nitrogen limitations directly reduce assimilation but do not directly interact with $\mathrm{CO}_{2}$ in the photosynthesis model. However, $\mathrm{CO}_{2}$ and the water budget are closely related through stomatal conductance since higher $\left[\mathrm{CO}_{2}\right]$ directly reduces stomatal conductance which reduces water demand and hence lessens water stress. Temperature affects productivity in several ways: there are effects on photosynthesis, respiration, phenology and growing season length, evapotranspiration which determines water demand and thus drought stress, and mineralization/decomposition and hence nutrient availability. Precipitation modestly determines the soil water content and hence the water available for uptake by the trees. It is important to note that $4 \mathrm{C}$ is not dynamically linked to other climate change-related disturbances such as insects or storm damage. Thus, 4C satisfies the criteria that Medlyn et al. (2011) defined to assess the suitability of models to address climate change effects on forest productivity to varying degree. If the effects of $\mathrm{CO}_{2}$ and of climate change-related disturbances are properly discussed, it can be used for studying climate change impacts in forest productivity.

A more detailed description of $4 \mathrm{C}$ can be found in the Electronic supplementary material (ESM) 1 . In the framework of this study, the different model processes have been validated at nine stands across Europe with detailed measurements from different sources. For a detailed description of the validation concept, data and results see the ESM 8.

\subsection{Data}

\subsubsection{Stand data}

The stand data used to initialize $4 \mathrm{C}$ stems from several sources. The largest part consists of individual tree data derived from the Level-II plots of the 'Pan-European Programme for Intensive and Continuous Monitoring of Forest Ecosystems' database (hereafter referred to as Level-II database) which represents typical forest stands in most European countries (de Vries et al. 2003) and is unique in spatial coverage. Additional sites that were added especially for model validation purposes were taken from a range of sources presented in Table 4 in the ESM. We focused on important tree species in Europe, namely Scots pine, Norway spruce, European beech and a generic oak (Sessile and Pedunculate oak). The latter two species were not distinguished in this study. Within the LevelII database we selected a large number of sites for which sufficient data was available to initialize $4 \mathrm{C}$ to cover most of Europe's growing conditions (for further information on site selection see Fig. 1 in the ESM). The final number of sites was 132 (Table 1 in the ESM) and covers the age, soil, and geographic distribution as well as the management history of European forests as far as data was available and as far as the Level-II database is considered to represent typical forests. Our selection does not represent the area or importance of a species in the individual countries. The 132 sites fell into 10 environmental zones as defined by Metzger et al. (2005) (Table 1).

Table 1 Number of stands per main tree species in each environmental zone (after Metzger et al. 2005)

\begin{tabular}{|c|c|c|c|c|c|}
\hline Environmental zone & Fagus sylvatica & Picea abies & Pinus sylvestris & Quercus robur/petraea & Total \\
\hline Alpine North (ALN) & - & 4 & 2 & - & 6 \\
\hline Boreal (BOR) & - & 6 & 12 & - & 18 \\
\hline Nemoral (NEM) & 3 & 8 & 3 & 1 & 15 \\
\hline Atlantic North (ATN) & 5 & 3 & 2 & - & 10 \\
\hline Alpine South (ALS) & 1 & 4 & 1 & - & 6 \\
\hline Continental (CON) & 15 & 14 & 14 & 4 & 47 \\
\hline Atlantic Central (ATC) & 9 & - & 5 & 4 & 18 \\
\hline Pannonian (PAN) & - & 1 & - & 1 & 2 \\
\hline Lusitanian (LUS) & - & - & 1 & 2 & 3 \\
\hline Mediterranean Mountains (MDM) & 4 & - & 3 & - & 7 \\
\hline Total & 37 & 40 & 43 & 12 & 132 \\
\hline
\end{tabular}




\subsubsection{Climate data, climate change scenarios, and representation of $\mathrm{CO}_{2}$ effects}

Our simulations were driven by daily time series of temperature, precipitation, relative humidity, global radiation, air pressure and wind speed for the past and the future. We used data of three different Regional Climate Models (RCM) driven by three different General Circulation Models (GCM) in the following RCM/GCM combinations: CCLM/ECHAM5, HadRM3/HadCM3 and HIRHAM3/Arpège. The data of the latter two RCM/GCM combinations have been taken from the ENSEMBLES project (van der Linden and Mitchell 2009) while the CCLM/ECHAM5 data are from Lautenschläger et al. (2009a, b, c, d, e, f). The choice of GCM/RCM combination was motivated by capturing a broad range of possible future climates. Over all the plots analyzed here, CCLM/ECHAM5 and HIRHAM3/Arpège project a more moderate warming than HadRM3/HadCM3 (see Table 2). CCLM/ECHAM5 also projects increases in annual precipitation sum while changes in annual precipitation sum are very small in HadRM3/HadCM3 and negative in HIRHAM3/Arpège. Furthermore, the RCMs differ in the seasonal distribution of the climatic variables (Déqué et al. 2007; van der Linden and Mitchell 2009) but this has not been assessed in this study.

For each RCM/GCM combination one realization for the period 1971-2000 was available for the past climate and one for the period 2001-2090 for the future climate according to the SRES $\mathrm{CO}_{2}$ emission scenario A1B (Nakicenovic et al. 2000). The A1B scenario storyline represents more or less a business as usual continuation of $\mathrm{CO}_{2}$ emissions. For CCLM, we also used a second realization for the period 1971-2000 and a corresponding second realization of the $\mathrm{A} 1 \mathrm{~B}$ run as well as two realizations of the SRES $\mathrm{CO}_{2}$ emission scenario $\mathrm{B} 1$ (Nakicenovic et al. 2000) also for the period 2001-2090. The $\mathrm{B} 1$ scenario storyline projects less $\mathrm{CO}_{2}$ emissions than the A1B scenario. This resulted in four realizations of three $\mathrm{RCM} / \mathrm{GCM}$ combinations for $\mathrm{A} 1 \mathrm{~B}$ and two realizations of one RCM/GCM combination for B1 (Fig. 2 in the ESM). For the data from the ENSEMBLES database, no B1-runs were available and also no realizations in the sense of the CCLM realizations. The use of different realizations refers to different starting points of the models in the decadal oscillation (For more information see the ESM 4). The combination of different GCM/RCM combinations, realizations and emission scenarios allows us to consider the effects of input uncertainty arising from climate models related to inter-model variation, intra-model variation and socioeconomic development respectively.

Since the RCMs do not always fit observed data (e.g. Hollweg et al. (2008) noted that generally summers are too cold and precipitation is too high in the baseline (19712000) CCLM runs), we corrected mean temperature and precipitation with data from a measured dataset (CRUPIK) for absolute and relative model bias respectively (ESM 5). The mean temperature of this dataset is a version of the CRU dataset (New et al. 1999; New et al. 2000; Mitchell and Jones 2005) corrected and homogenized at PIK (Österle et al. 2003). The precipitation dataset is a version of the Global Precipitation Climatology Centre (Fuchs 2008; Rudolf and Scheider 2005; Rudolf et al. 2010; Scheider et al. 2008) corrected and homogenized at PIK (Österle, personal communication).

This climate data were downscaled to the location of the 132 plots. To account for altitudinal dependencies of the climatic variables, we used information from a digital elevation model of the Global Land Cover Facility (USGS 2004) and external-drift-Kriging (Deutsch and Journel 1992). Wind speed did not show any height dependency and was interpolated using ordinary kriging (Deutsch and Journel 1992). After the interpolation, the data were checked for plausibility since the bias correction as well as the interpolation can introduce physically implausible values of daily weather. For example, the bias correction for precipitation using the relative model bias can lead to very high daily precipitation sums if the value to be corrected in the future is very different from the values used to derive the monthly correction factor (see ESM 5). Basically, this refers to daily extreme values or weather conditions which are at odds with long-term climatic conditions. These values were not deleted or replaced but reduced to physically plausible values.

Once the climate data were bias-corrected and downscaled, we generated a set of climate change scenarios for each site: each of the six realizations was dissected into three time slices of future time periods $(\mathrm{P} 1=2001-2030, \mathrm{P} 2=2031-2060$, and $\mathrm{P} 3=2061-2090$ ) yielding 18 different climate change scenarios. The time slices represent physically realistic combinations of temperature and precipitation and are treated as independent climate change scenarios. An aggregated analysis of the projected climate change for the 10 study regions can be found in Table 2 and Table 2 in the ESM.

Each of the 18 different climate change scenarios was then combined with an assumption on future $\left[\mathrm{CO}_{2}\right]$ - either constant at $350 \mathrm{ppm}$ or increasing corresponding to the $\mathrm{CO}_{2}$ emission scenarios A1B or B1 (see ESM 6) - to incorporate uncertainties about the persistence of $\mathrm{CO}_{2}$ effects. Constant $\left[\mathrm{CO}_{2}\right]$ represents the lower margin (i.e. an acclimation of photosynthesis to $\left[\mathrm{CO}_{2}\right]$ at $350 \mathrm{ppm}$ ), whereas increasing $\left[\mathrm{CO}_{2}\right]$ represents the upper margin (i.e. persisting stimulation of photosynthesis by $\left[\mathrm{CO}_{2}\right]$ ) of $\mathrm{CO}_{2}$ effects on NPP in our analysis.

Each of the 18 climate change scenarios was linked to its respective realization of the past climate (1971-2000) including either constant $\left[\mathrm{CO}_{2}\right]$ at $350 \mathrm{ppm}$ if an acclimation of photosynthesis to $\left[\mathrm{CO}_{2}\right]$ was considered or increasing 
Table 2 Change in mean annual temperature ( $T$ in degrees Celsius) and mean annual precipitation sum ( $P$ in percent) relative to the baseline climate of the period 1971-2000 simulated by each model per environmental zone (Metzger et al. 2005) (for abbreviations, see Table 1) and for all studied plots across Europe ('all plots') and each RCM/GCM combination (CCLM/ECHAM5 (CCLM), HadRM3/HadCM3 (HAD) and HIRHAM3/Arpège (HIR)), $\mathrm{CO}_{2}$ emission scenario (A1B or B1), realization $(\mathrm{R} 1$ or $\mathrm{R} 2)$ and time slice $(\mathrm{Base}=1971-2000, \mathrm{P} 1=2001-$ 2030, $\mathrm{P} 2=2031-2060$, and $\mathrm{P} 3=2061-2090)$ considered in this study

\begin{tabular}{|c|c|c|c|c|c|c|c|c|c|c|c|}
\hline & ALN & BOR & NEM & ATN & ALS & $\mathrm{CON}$ & ATC & PAN & LUS & MDM & All plots \\
\hline \multicolumn{12}{|l|}{ Change in $T\left({ }^{\circ} \mathrm{C}\right)$} \\
\hline CCLM-A1B-R1-P1 & 0.3 & 0.3 & 0.4 & 0.4 & 0.4 & 0.3 & 0.3 & 0.3 & 0.3 & 0.6 & 0.4 \\
\hline CCLM-A1B-R1-P2 & 1.5 & 1.5 & 1.4 & 1.4 & 1.4 & 1.3 & 1.4 & 1.4 & 1.5 & 1.8 & 1.4 \\
\hline CCLM-A1B-R1-P3 & 2.9 & 3.2 & 2.7 & 2.7 & 3.1 & 2.9 & 2.8 & 3.1 & 2.9 & 3.7 & 2.9 \\
\hline CCLM-B1-R1-P1 & 0.3 & 0.4 & 0.5 & 0.5 & 0.5 & 0.5 & 0.4 & 0.5 & 0.3 & 0.6 & 0.5 \\
\hline CCLM-B1-R1-P2 & 1.3 & 1.3 & 1.0 & 0.9 & 0.9 & 0.9 & 0.7 & 0.8 & 0.6 & 1.0 & 1.0 \\
\hline CCLM-B1-R1-P3 & 2.1 & 2.2 & 1.9 & 1.7 & 2.0 & 1.9 & 1.7 & 1.9 & 1.7 & 2.3 & 1.9 \\
\hline CCLM-A1B-R2-P1 & 0.9 & 0.9 & 0.9 & 0.6 & 0.7 & 0.7 & 0.5 & 0.7 & 0.5 & 0.7 & 0.7 \\
\hline CCLM-A1B-R2-P2 & 2.0 & 2.3 & 2.0 & 1.8 & 1.9 & 1.9 & 1.6 & 1.9 & 1.5 & 2.0 & 1.9 \\
\hline CCLM-A1B-R2-P3 & 3.3 & 3.4 & 3.0 & 2.8 & 3.2 & 3.0 & 2.9 & 3.2 & 2.8 & 3.6 & 3.1 \\
\hline CCLM-B1-R2-P1 & 1.1 & 1.2 & 1.0 & 0.8 & 0.8 & 0.8 & 0.7 & 0.8 & 0.6 & 0.8 & 0.9 \\
\hline CCLM-B1-R2-P2 & 1.6 & 1.7 & 1.4 & 1.2 & 1.3 & 1.2 & 1.1 & 1.2 & 1.2 & 1.5 & 1.3 \\
\hline CCLM-B1-R2-P3 & 2.4 & 2.5 & 2.0 & 1.9 & 2.2 & 2.0 & 1.9 & 2.2 & 1.9 & 2.5 & 2.1 \\
\hline HAD-A1B-R1-P1 & 1.2 & 1.5 & 1.3 & 1.1 & 1.1 & 1.1 & 1.0 & 1.1 & 0.8 & 0.9 & 1.2 \\
\hline HAD-A1B-R1-P2 & 3.1 & 3.3 & 2.9 & 2.6 & 2.8 & 2.8 & 2.4 & 2.7 & 2.2 & 2.9 & 2.8 \\
\hline HAD-A1B-R1-P3 & 4.0 & 4.3 & 3.9 & 3.6 & 3.9 & 3.8 & 3.5 & 3.9 & 3.2 & 4.1 & 3.8 \\
\hline HIR-A1B-R1-P1 & 0.6 & 0.8 & 0.6 & 0.4 & 0.6 & 0.5 & 0.5 & 0.6 & 0.6 & 0.7 & 0.6 \\
\hline HIR-A1B-R1-P2 & 1.8 & 1.9 & 1.4 & 1.3 & 1.5 & 1.3 & 1.3 & 1.4 & 1.7 & 1.8 & 1.5 \\
\hline HIR-A1B-R1-P3 & 3.0 & 3.2 & 2.2 & 1.9 & 2.1 & 1.9 & 1.9 & 2.0 & 2.0 & 2.5 & 2.2 \\
\hline \multicolumn{12}{|l|}{ Change in $\mathrm{P}(\%)$} \\
\hline CCLM-A1B-R1-P1 & 6.0 & 4.3 & 7.4 & 2.5 & 1.0 & 3.8 & 2.0 & 8.5 & -4.1 & -6.2 & 3.3 \\
\hline CCLM-A1B-R1-P2 & 10.4 & 7.6 & 10.7 & 3.4 & -0.6 & 4.3 & 1.1 & 2.4 & -8.4 & -12.8 & 3.8 \\
\hline CCLM-A1B-R1-P3 & 16.4 & 16.3 & 15.0 & 4.1 & -0.5 & 3.1 & 1.7 & 0.7 & -10.6 & -17.6 & 5.1 \\
\hline CCLM-B1-R1-P1 & 0.5 & 3.9 & 5.1 & 5.3 & 5.3 & 5.8 & 7.0 & 7.9 & -0.1 & -1.2 & 4.8 \\
\hline CCLM-B1-R1-P2 & 5.6 & 8.0 & 7.2 & 4.9 & 4.1 & 4.7 & 5.2 & 6.7 & -1.3 & 1.2 & 5.3 \\
\hline CCLM-B1-R1-P3 & 13.2 & 12.5 & 11.5 & 3.2 & 2.0 & 4.4 & 1.0 & 4.7 & -6.9 & -11.7 & 5.0 \\
\hline CCLM-A1B-R2-P1 & 3.9 & 6.2 & 4.7 & 4.3 & 3.0 & 4.1 & 3.7 & -0.5 & 1.5 & -2.5 & 3.9 \\
\hline CCLM-A1B-R2-P2 & 7.6 & 11.6 & 11.0 & 6.3 & 0.6 & 3.4 & 3.6 & -2.5 & -1.0 & -7.6 & 4.9 \\
\hline CCLM-A1B-R2-P3 & 15.4 & 17.3 & 14.8 & 4.9 & -4.0 & 1.8 & 0.0 & -8.6 & -8.5 & -16.9 & 4.3 \\
\hline CCLM-B1-R2-P1 & 4.3 & 6.3 & 4.5 & 1.5 & 0.7 & 0.8 & 0.8 & -3.2 & 1.1 & -2.9 & 1.9 \\
\hline CCLM-B1-R2-P2 & 6.0 & 10.8 & 8.4 & 3.3 & 0.4 & 2.7 & 0.3 & -3.5 & -2.7 & -5.9 & 3.6 \\
\hline CCLM-B1-R2-P3 & 9.5 & 11.9 & 11.4 & 7.2 & -0.3 & 3.7 & 1.3 & -7.0 & -4.5 & -9.9 & 4.7 \\
\hline HAD-A1B-R1-P1 & 8.3 & 6.6 & 1.9 & -0.7 & -0.8 & 1.2 & 0.9 & -0.7 & -0.8 & -0.4 & 1.9 \\
\hline HAD-A1B-R1-P2 & 16.0 & 13.2 & 5.9 & -2.2 & -5.2 & -1.6 & -6.2 & -5.9 & -15.4 & -13.0 & 0.3 \\
\hline HAD-A1B-R1-P3 & 16.6 & 17.4 & 7.6 & -5.1 & -6.2 & -1.1 & -7.4 & -7.2 & -14.5 & -15.7 & 0.7 \\
\hline HIR-A1B-R1-P1 & 6.6 & 5.0 & -0.3 & 3.0 & 3.4 & 3.9 & 3.3 & 2.3 & 3.1 & 0.5 & 3.3 \\
\hline HIR-A1B-R1-P2 & 5.6 & 2.0 & -1.4 & -8.5 & -5.5 & -1.3 & -7.0 & -0.5 & -7.4 & -9.9 & -2.6 \\
\hline HIR-A1B-R1-P3 & 11.0 & 4.2 & -9.3 & -16.3 & -13.5 & -9.6 & -15.2 & -12.5 & -15.8 & -19.5 & -8.9 \\
\hline
\end{tabular}

$\left[\mathrm{CO}_{2}\right]$ corresponding to the Mauna Loa data (Tans and Keeling 2012) if a persistence of $\mathrm{CO}_{2}$ effects was considered. This lead to four realizations of past climate times two assumptions about the $\mathrm{CO}_{2}$ effects equals eight baseline input sets.

\subsubsection{Soil data}

The 4C soil submodel requires information about soil physical and chemical properties such as soil texture, bulk density, $\mathrm{pH}$ values and carbon and nitrogen content for different 
soil layers. We used different sources of soil data for the 132 sites. Since the Level-II database does not provide sufficient soil information to initialize 4C, we linked each Level-II site with the soil information of the European soil database (ESBN 2004). This is described in more detail in the ESM 7 and 8a. For Germany the soil data base BÜK 1000 (BGR 2004) was used.

\subsection{Simulation experiment}

To simulate the effects of climate change and our assumptions about the persistence of $\mathrm{CO}_{2}$ effects, we ran the same 4C initialization (hence the same stand and soil initial conditions) at each of the 132 sites for the four baseline climates and the 18 climate change scenarios each lasting for a period of 30 years and under the assumptions of an acclimation to $\left[\mathrm{CO}_{2}\right]$ or a persistence of $\mathrm{CO}_{2}$ effects. The stands were not managed during these 30-year-simulations and soil vegetation was not considered. This approach allows us to keep the age structure of the studied stands constant in between different time periods and thus minimize effects of ageing and long-term forest development on forest productivity.

To display climate change impacts, we analyzed the absolute change in NPP, hence the difference (in megagrams carbon (C) ha ${ }^{-1}$ year $^{-1}$ ) between mean annual NPP over the simulation period and mean annual NPP of the baseline simulation. Thus, we ended up with 1,056 (132 sites times four baseline climates times two $\mathrm{CO}_{2}$ assumptions) simulation runs for the baseline period and 4,752 (132 sites times 18 climate change scenarios times two $\mathrm{CO}_{2}$ assumptions) for the future.

\section{Results}

3.1 NPP changes at the European level in the environmental zones

Over all scenarios (i.e. time slices, realizations, $\mathrm{CO}_{2}$ emission scenarios and RCMs), the changes in NPP are strongly influenced by our assumptions on $\left[\mathrm{CO}_{2}\right]$ (Table 3; Figs. 1 and 2). With persistent $\mathrm{CO}_{2}$ effects, the NPP increases in most simulations and in most regions with few exceptions mainly in the Mediterranean Mountains and Lusitania (Fig. 1). The median of the NPP change ranges between 0.6 and $1.2 \mathrm{Mg} \mathrm{C} \mathrm{ha}^{-1}$ year $^{-1}$ in the different regions. There seems to be a peak of NPP increase in central European environmental zones but the difference in NPP change in between groups is not very large. The variation of the NPP changes at the stand-level as expressed by the standard deviation across the different scenarios, time slices and RCMs is quite large (Fig. 2). This translates into large variations of NPP change at the regional level and the changes in NPP encountered in individual regions span a

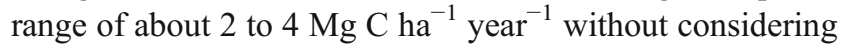
outliers (Fig. 1).

Assuming an acclimation of photosynthesis to $\left[\mathrm{CO}_{2}\right]$, the changes in NPP are much smaller, span a range of about 1 to 3.4 $\mathrm{Mg} \mathrm{C} \mathrm{ha}{ }^{-1}$ year $^{-1}$ without considering outliers and turn negative for some scenarios in all environmental zones (Fig. 1). The median of the NPP change ranges between -0.3 and $0.3 \mathrm{MgC} \mathrm{ha}^{-1}$ year $^{-1}$. There is a tendency towards decreasing NPP changes from north to south (Fig. 1). The variation of the changes in NPP across the different scenarios at the stand-level is mostly lower than in the case of persistent $\mathrm{CO}_{2}$ effects (Fig. 2). This translates into lower variations in NPP change at the regional level although it is notable that there are many positive and negative outliers (Fig. 1).

These regional patterns of higher NPP change and increasing variability under persistent $\mathrm{CO}_{2}$ effects are consistent with the results of the individually simulated forest stands over Europe (Fig. 2). Figure 2 also shows that with an acclimation of photosynthesis to $\left[\mathrm{CO}_{2}\right]$ the changes in NPP are strongly regionally stratified, with increases in Northern, decreases in Southern and Western and ambivalent responses in Central and Eastern Europe.

Over the three future time slices considered, NPP increases from the first to the third time slice in most environmental zones under persistent $\mathrm{CO}_{2}$ effects (Table 3). Only in few cases in the Mediterranean Mountains and in Lusitania, the NPP is lower in the third time slice compared with the second or in the second lower compared with the first. Under an acclimation of photosynthesis to $\left[\mathrm{CO}_{2}\right]$, the temporal patterns of NPP change are more diverse (Table 3 ). In environmental zones located in higher latitudes and altitudes (ALN, ALS, BOR, and NEM), NPP increases from the first to the third time slice of most climate change scenarios. In contrast, NPP decreases from the first to the third time slice of most climate change scenarios in the southwestern and southeastern environmental zones (LUS, MDM, and PAN). In the Atlantic and Continental environmental zones (ATC, ATN, and CON), the changes in NPP are less consistent and do not show clear increasing or decreasing trends over the three time slices. More information on changes in NPP in the individual time slices, RCM/GCM combinations, realizations and assumptions on $\left[\mathrm{CO}_{2}\right]$ is presented in Figs. 14, $15,16,17,18$, and 19 in the ESM. Furthermore, Table 3 shows that the effect of the $\mathrm{CO}_{2}$ emission scenario on NPP change is lower than the choice of the RCM/GCM combination. For example, the NPP change ranges from -0.04 to $0.25 \mathrm{Mg} \mathrm{C} \mathrm{ha}^{-1}$ year $^{-1}$ over the CCLM A1B and B1 scenario runs with an acclimation of photosynthesis to $\left[\mathrm{CO}_{2}\right]$ in the Boreal environmental zone, while it ranges from -0.02 to $1.08^{\circ} \mathrm{Mg} \mathrm{C}^{-1}$ year $^{-1}$ over the A1B scenario runs only but of the three RCMs. Table 3 also shows that the effect of 
Table 3 Changes in net primary productivity (NPP; in megagrams C per hectare per year) in each environmental zone (Metzger et al. 2005) (for abbreviations, see Table 1) and for each RCM/GCM combination (CCLM/ ECHAM5 (CCLM), HadRM3/HadCM3 (HAD) and HIRHAM3/Arpège
(HIR)), $\mathrm{CO}_{2}$ emission scenario (A1B or $\mathrm{B} 1$ ), realization (R1 or R2), and time slice $(\mathrm{P} 1=2001-2030, \mathrm{P} 2=2031-2060$, and P3 $=2061-2090)$ considered in this study

\begin{tabular}{|c|c|c|c|c|c|c|c|c|c|c|}
\hline & ALN & BOR & ATN & NEM & ALS & $\mathrm{CON}$ & ATC & PAN & LUS & MDM \\
\hline \multicolumn{11}{|c|}{ Acclimation to $\mathrm{CO}_{2}$ effects } \\
\hline CCLM-A1B-R1-P1 & 0.02 & 0.02 & -0.02 & -0.04 & -0.03 & -0.17 & -0.16 & -0.30 & -0.59 & -0.45 \\
\hline CCLM-A1B-R1-P2 & 0.16 & 0.04 & 0.09 & 0.10 & 0.29 & -0.08 & -0.06 & -0.40 & -0.34 & -0.34 \\
\hline CCLM-A1B-R1-P3 & 0.27 & 0.24 & 0.29 & 0.20 & 0.78 & 0.13 & -0.17 & -0.68 & -1.09 & -1.42 \\
\hline CCLM-B1-R1-P1 & 0.06 & 0.10 & 0.08 & 0.16 & 0.06 & 0.04 & -0.09 & -0.13 & -0.20 & -0.11 \\
\hline CCLM-B1-R1-P2 & 0.31 & 0.17 & -0.18 & -0.06 & -0.04 & -0.21 & -0.26 & -0.29 & -0.28 & -0.37 \\
\hline CCLM-B1-R1-P3 & 0.24 & 0.08 & 0.15 & 0.19 & 0.51 & 0.09 & 0.04 & -0.04 & -0.74 & -0.75 \\
\hline CCLM-A1B-R2-P1 & 0.44 & 0.14 & -0.01 & 0.11 & 0.11 & 0.06 & 0.00 & 0.15 & -0.10 & -0.06 \\
\hline CCLM-A1B-R2-P2 & 0.50 & 0.25 & 0.19 & 0.24 & 0.49 & 0.33 & 0.17 & 0.26 & 0.00 & 0.03 \\
\hline CCLM-A1B-R2-P3 & 0.67 & 0.22 & 0.35 & 0.25 & 0.85 & 0.32 & -0.05 & -0.30 & -0.62 & -0.68 \\
\hline CCLM-B1-R2-P1 & 0.44 & 0.16 & 0.14 & 0.22 & 0.26 & 0.23 & 0.14 & 0.35 & -0.13 & 0.15 \\
\hline CCLM-B1-R2-P2 & 0.33 & -0.04 & -0.02 & -0.01 & 0.23 & 0.02 & 0.01 & 0.14 & -0.08 & -0.11 \\
\hline CCLM-B1-R2-P3 & 0.52 & 0.24 & 0.12 & 0.06 & 0.64 & 0.26 & 0.07 & -0.18 & -0.42 & -0.47 \\
\hline HAD-A1B-R1-P1 & 0.54 & 0.37 & 0.36 & 0.23 & 0.46 & 0.097 & -0.09 & -0.11 & -0.13 & 0.07 \\
\hline HAD-A1B-R1-P2 & 0.96 & 0.87 & 0.61 & 0.59 & 1.11 & 0.266 & -0.48 & -0.75 & -1.24 & -0.53 \\
\hline HAD-A1B-R1-P3 & 1.10 & 1.08 & 0.64 & 0.76 & 1.25 & 0.275 & -0.60 & -0.92 & -1.44 & -0.68 \\
\hline HIR-A1B-R1-P1 & 0.00 & -0.02 & -0.03 & 0.02 & 0.06 & 0.12 & -0.10 & 0.04 & 0.17 & 0.08 \\
\hline HIR-A1B-R1-P2 & 0.45 & 0.30 & -0.25 & 0.05 & 0.15 & -0.30 & -0.42 & -0.37 & -0.18 & -0.22 \\
\hline HIR-A1B-R1-P3 & 0.46 & 0.19 & -0.33 & 0.09 & -0.26 & -0.63 & -0.94 & -1.09 & -0.98 & -0.89 \\
\hline \multicolumn{11}{|l|}{ Persistent $\mathrm{CO}_{2}$ effects } \\
\hline CCLM-A1B-R1-P1 & 0.21 & 0.22 & 0.38 & 0.28 & 0.36 & 0.26 & 0.30 & 0.22 & -0.09 & 0.02 \\
\hline CCLM-A1B-R1-P2 & 0.60 & 0.56 & 1.06 & 0.86 & 1.24 & 0.97 & 1.09 & 0.91 & 0.92 & 0.88 \\
\hline CCLM-A1B-R1-P3 & 0.94 & 1.00 & 1.95 & 1.43 & 2.45 & 1.99 & 1.82 & 1.62 & 1.04 & 0.62 \\
\hline CCLM-B1-R1-P1 & 0.24 & 0.30 & 0.45 & 0.49 & 0.43 & 0.45 & 0.33 & 0.37 & 0.25 & 0.32 \\
\hline CCLM-B1-R1-P2 & 0.71 & 0.57 & 0.57 & 0.55 & 0.69 & 0.60 & 0.60 & 0.74 & 0.67 & 0.58 \\
\hline CCLM-B1-R1-P3 & 0.74 & 0.64 & 1.23 & 1.06 & 1.60 & 1.29 & 1.34 & 1.52 & 0.72 & 0.66 \\
\hline CCLM-A1B-R2-P1 & 0.64 & 0.34 & 0.38 & 0.43 & 0.49 & 0.48 & 0.44 & 0.68 & 0.34 & 0.40 \\
\hline CCLM-A1B-R2-P2 & 0.97 & 0.77 & 1.17 & 1.03 & 1.46 & 1.43 & 1.28 & 1.68 & 1.18 & 1.21 \\
\hline CCLM-A1B-R2-P3 & 1.39 & 0.98 & 2.01 & 1.49 & 2.54 & 2.12 & 1.89 & 2.03 & 1.37 & 1.38 \\
\hline CCLM-B1-R2-P1 & 0.63 & 0.35 & 0.53 & 0.54 & 0.64 & 0.65 & 0.58 & 0.87 & 0.31 & 0.59 \\
\hline CCLM-B1-R2-P2 & 0.69 & 0.36 & 0.74 & 0.59 & 0.99 & 0.84 & 0.89 & 1.22 & 0.85 & 0.84 \\
\hline CCLM-B1-R2-P3 & 1.03 & 0.81 & 1.22 & 0.91 & 1.76 & 1.48 & 1.36 & 1.34 & 1.01 & 0.91 \\
\hline HAD-A1B-R1-P1 & 0.82 & 0.64 & 0.91 & 0.70 & 0.96 & 0.68 & 0.49 & 0.53 & 0.43 & 0.52 \\
\hline HAD-A1B-R1-P2 & 1.73 & 1.69 & 2.13 & 1.85 & 2.53 & 1.89 & 1.09 & 0.95 & 0.13 & 0.65 \\
\hline HAD-A1B-R1-P3 & 2.28 & 2.27 & 3.13 & 2.77 & 3.61 & 2.91 & 1.96 & 1.80 & 0.81 & 1.26 \\
\hline HIR-A1B-R1-P1 & 0.19 & 0.19 & 0.50 & 0.40 & 0.58 & 0.70 & 0.46 & 0.64 & 0.67 & 0.50 \\
\hline HIR-A1B-R1-P2 & 0.92 & 0.86 & 1.14 & 1.04 & 1.49 & 1.17 & 1.06 & 1.09 & 1.14 & 0.89 \\
\hline HIR-A1B-R1-P3 & 1.18 & 1.06 & 1.87 & 1.67 & 1.81 & 1.68 & 1.42 & 1.30 & 1.12 & 0.91 \\
\hline
\end{tabular}

different realizations of CCLM on NPP change can be larger than the effect of the $\mathrm{CO}_{2}$ emission scenario. For example, the NPP change in the Alpine North environmental zone ranges from 0.02 to $0.31 \mathrm{Mg} \mathrm{C} \mathrm{ha}{ }^{-1}$ year $^{-1}$ over the first realization of the CCLM A1B and B1 scenario and from 0.33 to $0.67 \mathrm{MgC} \mathrm{ha}^{-1}$ year $^{-1}$ over the second realization.
3.2 NPP changes at the species level

At the species level, the differentiation is also strongest between persistent $\mathrm{CO}_{2}$ effects and an acclimation of photosynthesis to $\left[\mathrm{CO}_{2}\right]$ (Fig. 3). Without considering outliers, the change in NPP ranges from 0 to $4 \mathrm{Mg} \mathrm{C} \mathrm{ha}{ }^{-1}$ year $^{-1}$ for 
Fig. 1 Change in net primary productivity (NPP; in megagrams $\mathrm{C}$ per hectare per year) in each environmental zone (Metzger et al. 2005) (for abbreviations, see Table 1; color codes as in Fig. 2) over all climate change scenarios for simulations with persistent $\mathrm{CO}_{2}$ effects (top) and acclimation of photosynthesis to $\left[\mathrm{CO}_{2}\right]$

(bottom). The boxplots show the following information: thick line, median; bottom and top of the box, 25th and 75th percentiles; and whiskers, maximum value or 1.5 times the interquartile range of the data depending on which is smaller. Points $=$ outliers larger than 1.5 times interquartile range

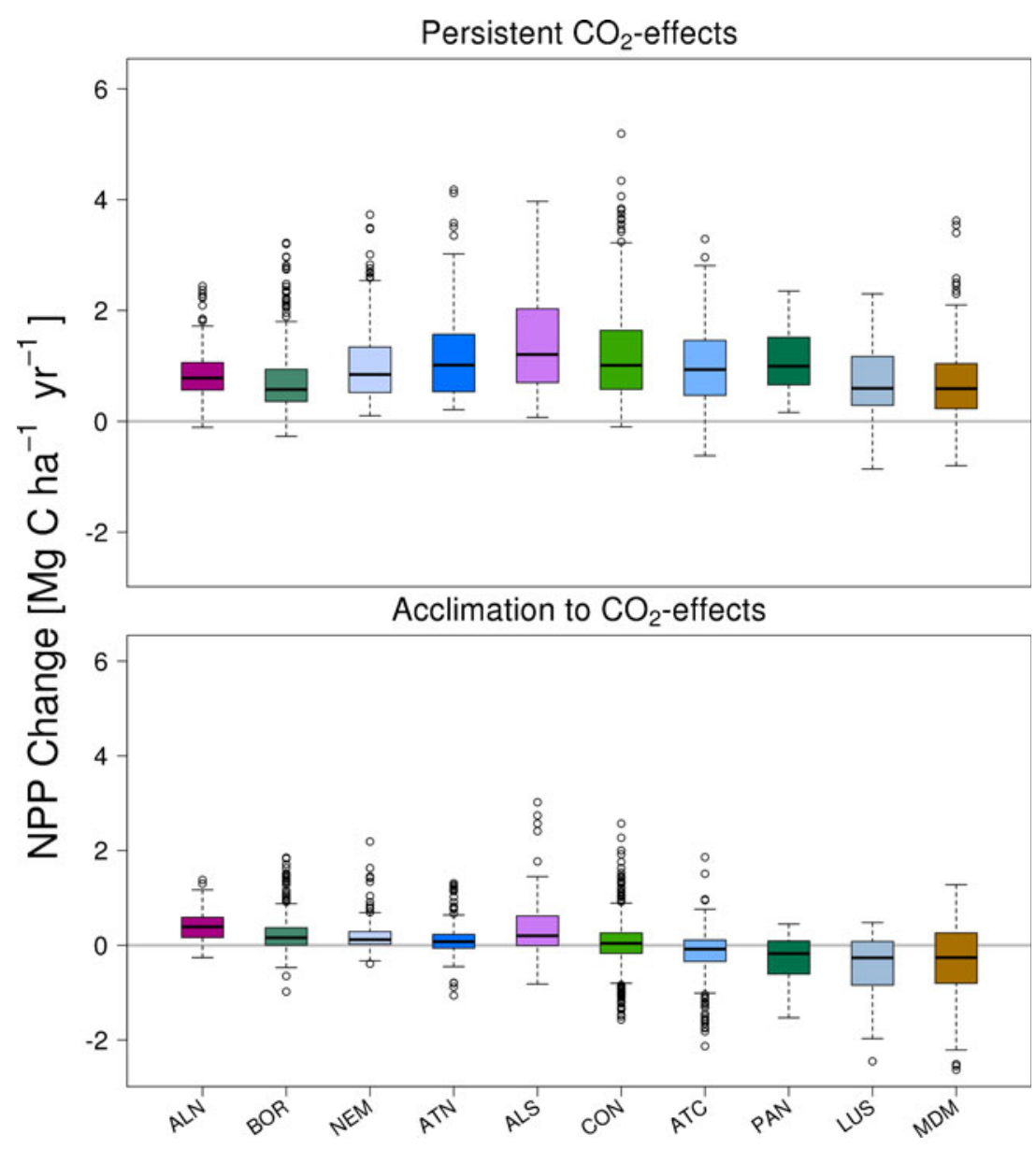

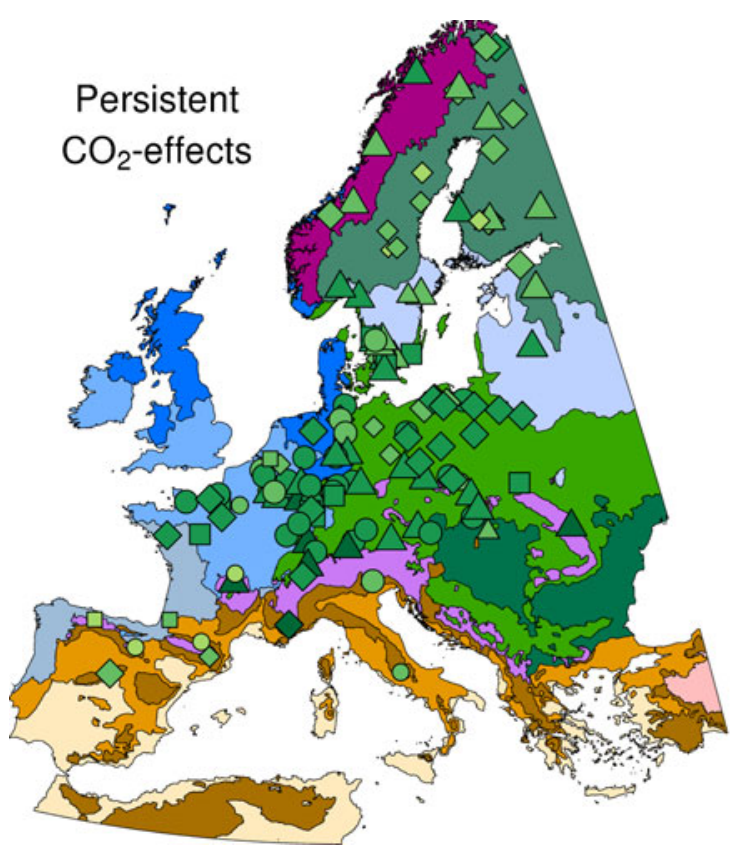

Fig. 2 Change in net primary productivity (NPP; in megagrams C per hectare per year) for each site averaged over all climate change scenarios for simulations with persistent $\mathrm{CO}_{2}$ effects (left) and acclimation of

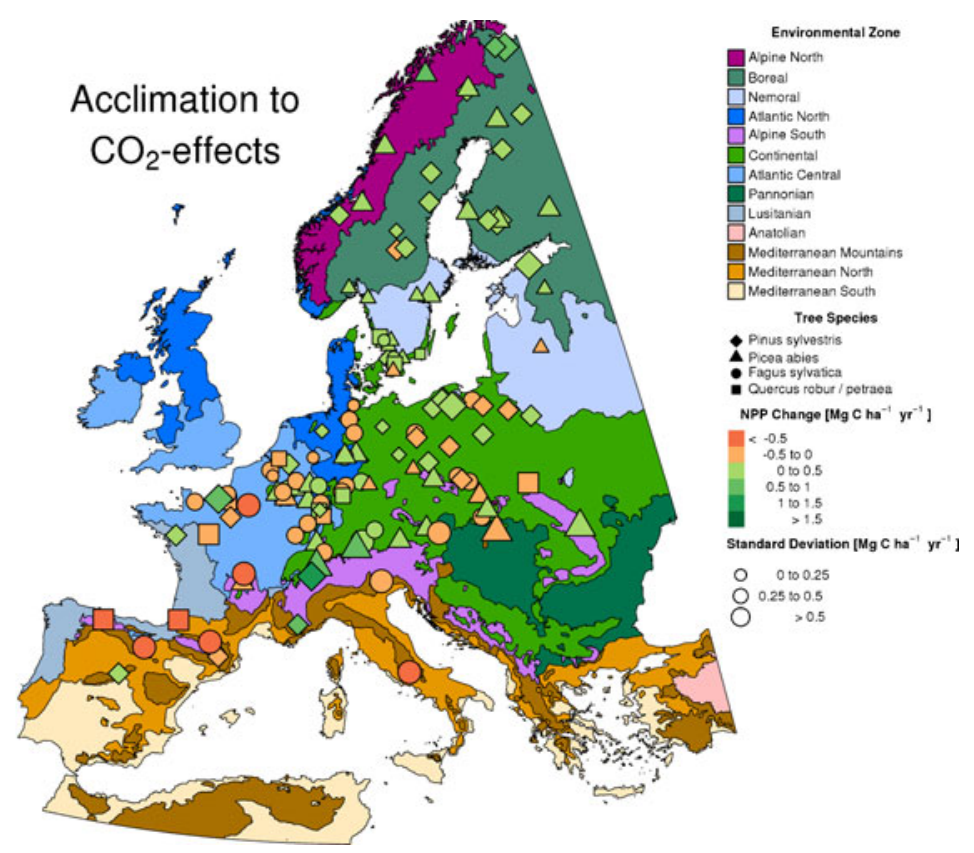

photosynthesis to $\left[\mathbf{C O}_{2}\right]$ (right). The environmental zones follow the classification of Metzger et al. (2005) 
Fig. 3 Change in net primary productivity (NPP; in megagrams $\mathrm{C}$ per hectare per year) for each tree species in each environmental zone (Metzger et al. 2005) (for abbreviations, see Table 1) over all climate change scenarios for simulations with acclimation of photosynthesis to $\left[\mathrm{CO}_{2}\right]$ and persistent $\mathrm{CO}_{2}$ effects. Boxplots defined as in Fig. 1

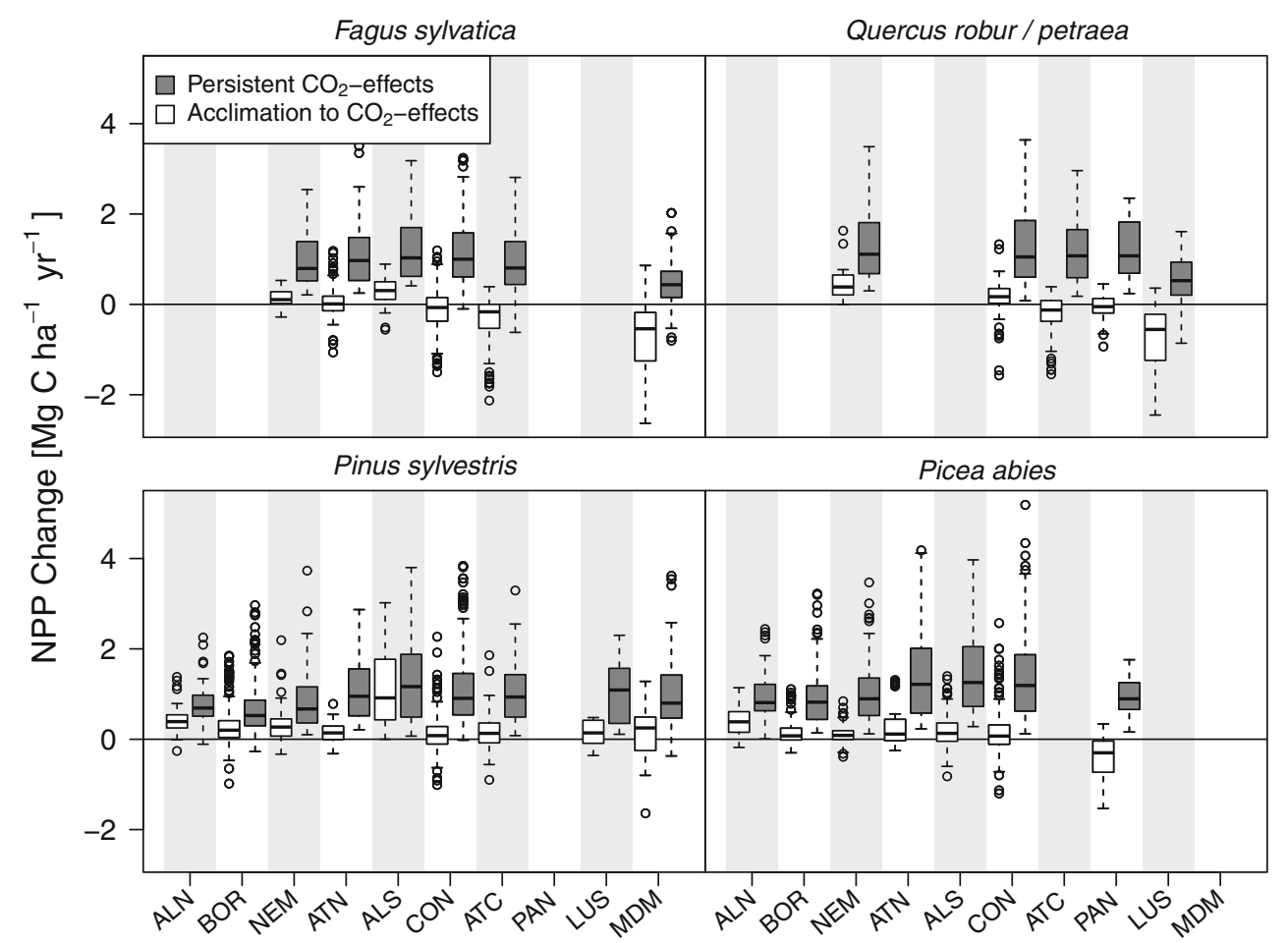

Norway spruce and from -0.2 to $3.9 \mathrm{Mg} \mathrm{C} \mathrm{ha}^{-1}$ year $^{-1}$ for Scots pine under persistent $\mathrm{CO}_{2}$ effects and from -1.5 to 1.1 Mg C ha ${ }^{-1}$ year $^{-1}$ for Norway spruce and from -0.9 to $3 \mathrm{Mg} \mathrm{C} \mathrm{ha}^{-1}$ year $^{-1}$ for Scots pine under an acclimation of photosynthesis to $\left[\mathrm{CO}_{2}\right]$ in the environmental zones. For broad-leaved species the range spans -0.5 to $3.1 \mathrm{Mg}$ $\mathrm{C} \mathrm{ha}{ }^{-1}$ year $^{-1}$ for European beech and -0.9 t0 $3.7 \mathrm{Mg}$ $\mathrm{C} \mathrm{ha}^{-1}$ year $^{-1}$ for the oaks under persistent $\mathrm{CO}_{2}$ effects and -2.7 to $0.9 \mathrm{Mg} \mathrm{C} \mathrm{ha}^{-1}$ year $^{-1}$ for European beech and -2.5 to $0.7 \mathrm{Mg} \mathrm{C}^{-1}$ year $^{-1}$ for the oaks under an acclimation of photosynthesis to $\left[\mathrm{CO}_{2}\right]$ in the environmental zones. Coniferous stands show mostly a positive median NPP changes in the different environmental zones. Negative median NPP changes of the broad-leaved species occur under an acclimation of photosynthesis to $\left[\mathrm{CO}_{2}\right]$ in the majority of the environmental zones. The regional patterns are comparable for European beech, the oaks and Norway spruce under an acclimation of photosynthesis to $\left[\mathrm{CO}_{2}\right]$ with a (slightly) decreasing trend in NPP change from north to south. For Scots pine under an acclimation of photosynthesis to $\left[\mathrm{CO}_{2}\right]$ and for all species under persistent $\mathrm{CO}_{2}$ effects there is no such trend.

\section{Discussion}

This paper shows that for the forest stands and climate change scenarios chosen, forest productivity in Europe is likely to change under climate change but that the exact amount and partly even the direction of this change depends very much on the choice of the climate change scenario (hence the severity and pace of climate change) and on the persistence of $\mathrm{CO}_{2}$ effects on forest productivity. There have already been a considerable number of model studies investigating forest productivity changes under climate change at the forest stand scale (e.g. review by Reyer et al. 2012). The present study complements other European studies in many important aspects: We use typical, existing forest stands which have a defined age, density, site and climate and represent the current species composition as driven by past forest management rather than the potential natural vegetation. We also simulate tree species rather than plant functional types which is usually done in applications at such a large scale (e.g. by Morales et al. 2007). Furthermore, we apply the same model all over Europe, for a large number of stands and for several tree species, which is not common for stand-scale PBMs (e.g. Kellomäki and Leinonen 2005). Additionally, our results are regionalized using detailed environmental zones according to Metzger et al. (2005). Finally, we explicitly consider uncertainties of $\mathrm{CO}_{2}$ effects on forest productivity by simulating persistent $\mathrm{CO}_{2}$ effects and an acclimation of photosynthesis to $\left[\mathrm{CO}_{2}\right]$ which embraces the upper and lower range of the physiological response to $\left[\mathrm{CO}_{2}\right]$ respectively (Ainsworth and Long 2005; Pinkard et al. 2010). The most closely related study to date has been carried out by Wamelink et al. (2009) which used a similar set of forest stands. However, also in comparison with this study there are several important methodological differences: Firstly, we use a mechanistic formulation of photosynthesis at a weekly resolution to calculate NPP and not annual scaling factors which allows us to include $\left[\mathrm{CO}_{2}\right]$ and water limitation effects on weekly photosynthesis. 
Secondly, our approach includes effects of climate change on growing season length and hence of feedbacks such as a longer growing season inducing a longer period of carbon assimilation and exposure to increasing concentrations of $\left[\mathrm{CO}_{2}\right]$ leading to higher productivity but also to higher risk of soil water depletion already comparably early in the vegetation period and subsequent productivity losses. Thirdly, we did not calibrate $4 \mathrm{C}$ on biomass or any other data from the Level-II database. Fourthly, we use several climate change scenarios to assess climate change scenario uncertainties. The climate change scenarios were generated by three different RCMs and then bias corrected for temperature and precipitation and interpolated to the sites. This shows that our study is unique in its approach. Despite these methodological differences, it is valuable to compare our results with other studies to assess if our study corroborates or contradicts earlier efforts.

\subsection{NPP changes in Europe}

Wamelink et al. (2009) analyzed the change in carbon sequestration under the $\mathrm{A} 2 \mathrm{CO}_{2}$ emission scenario until 2070 on a similar set of Level-II sites and found a comparable pattern of increasing productivity in the north and potentially decreasing productivity in the south. In their analysis, the importance of a changing climate was however larger and the importance of $\mathrm{CO}_{2}$ effects lower probably since they used the A2 $\mathrm{CO}_{2}$ emission scenario which features stronger changes in climate but also due to their different formulation of $\mathrm{CO}_{2}$ effects on productivity (see "Discussion" above). Although studying slightly different time periods, regions, and climate change scenarios, Morales et al. (2007) found similar magnitudes of NPP change and similar regional pattern as this study. They also identified Southwestern Europe as the most sensitive region, while NPP changes were positive in Northern Europe and in the Alps. Qualitatively, our results are also comparable to those of model studies using even more different datasets and modelling approaches (e.g. Eggers et al. 2008; Milne and van Oijen 2005).

Although our model study is methodologically very different from the past data-driven analysis, it is interesting to consider whether our results are in line with evidence from data-driven analyses. Our results show that changes in productivity observed in the past are likely to continue. A review by Boisvenue and Running (2006) found that several studies show increasing productivity in temperate and boreal Europe. Vayreda et al. (2012) found that the northern/ northwestern mountain areas of the Iberian Peninsula which are dominated by boreal and temperate tree species at the edge of their distribution range are already showing negative effects of warmer temperatures. Our results project these trends to continue although their magnitude depends strongly on the persistence of $\mathrm{CO}_{2}$ effects.
The changes in productivity we simulated are related to a number of processes in $4 \mathrm{C}$ (see "The model 4C") and depend on the regional variations in current and future climate. Generally, the higher the mean annual temperature, the higher also the risk of negative productivity changes occur with climate change (Table 3; Table 2 in the ESM). Furthermore, the RCMs differ in the seasonal variation in climate change (Déqué et al. 2007; van der Linden and Mitchell 2009), an effect not assessed in this study. Moreover, there are regional variations in the magnitude of climate change (Table 2). For example, the plots we simulated in the Mediterranean Mountains were in many scenarios also facing the strongest increase in temperature combined with decreasing precipitation (Table 2). These issues partly explain the variation in our results in between the different sites and environmental zones. However, these results are also partly determined by the soil and stand structure prevalent at any site. Therefore, analysis of the interactions between soil properties, stand attributes and also seasonal distributions of climate would require detailed site-level analyses.

\subsection{NPP changes at the species level}

At first sight, the good performance of Norway spruce in terms of projected NPP changes in this study seems to partly contradict concerns about Norway spruce's vulnerability to climate change. Despite past productivity increases in Norway spruce (Kahle et al. 2008) other studies highlight the strong sensitivity of Norway spruce to climate change in Central Europe (e.g. Kölling et al. 2009). In our study, this is however a matter of plot selection. Five of the selected Norway spruce plots feature a mean annual temperature above $8{ }^{\circ} \mathrm{C}$ and an annual precipitation sum lower than $800 \mathrm{~mm}$ in the period 1971-2000 (a threshold considered by Kölling et al. (2009) to indicate warm-dry Norway spruce forests which are especially vulnerable). For these plots, the $4 \mathrm{C}$ simulations actually show decreasing productivity in most of the three climate change time slices under an acclimation of photosynthesis to $\left[\mathrm{CO}_{2}\right]$ - thus confirming the concerns about Norway spruce's vulnerability to climate change. Many of the remaining Norway spruce stands are located in Northern Europe, where growing conditions are more favourable for Norway spruce. Although Scots pine is generally considered more robust against a changing climate than Norway spruce there are also concerns about Scots pine decline at extreme sites and at the southern limit of its distribution (Galiano et al. 2010; Rebetez and Dobbertin 2004; Reich and Oleksyn 2008) which are also apparent in our results if the simulations under an acclimation of photosynthesis to $\left[\mathrm{CO}_{2}\right]$ are considered.

The stands dominated by European beech and oak in our dataset show decreasing NPP under some climate change scenarios and an acclimation of photosynthesis to $\left[\mathrm{CO}_{2}\right]$. This finding is interesting since signs of beech decline in Southern Europe have already been observed (Jump et al. 2006; 
Piovesan et al. 2008). However, in general European beech is considered as competitive and climate-resilient in Central Europe (Ammer et al. 2005) although a positive growth response depends on a multitude of environmental and site factors (Geßler et al. 2007). Regarding the responses of oak to climate change in our dataset, it is important to note that the number of oak stands available for our analysis is considerably lower than for the other tree species and this may induce strong sensitivities of the response to extreme sites and climate.

In general, the different responses of coniferous and broadleaved species in our study are partly explained by the geographical distribution of the Level-II plots. There are more broadleaved stands located in environmental zones where climate conditions become very warm and drier while many of the coniferous stands are located in Northern Europe where conditions for forest growth even improve. This does not preclude that we find decreasing productivity for all tree species, mostly under the more severe climate change scenarios towards the end of the century and under an acclimation of photosynthesis to $\left[\mathrm{CO}_{2}\right]$. Besides these general differences due to the geographic distribution and the number of plots studies per species, the responses of the individual tree species to climate change are less pronounced than recent dendrochronological analyses suggest (Bontemps et al. 2012; Kint et al. 2012). This highlights that the species-specific parameters that determine the differences in between tree species in $4 \mathrm{C}$ are not sensitive enough to the differences in between the tree species at larger geographical scales such as an environmental zone or even Europe. Another important issue here is that the current species parameterization of $4 \mathrm{C}$ for oak does not differentiate between $Q$. robur and $Q$. petraea although these are different species with distinct ecology and distribution. The species-specific parameters of $4 \mathrm{C}$ do not capture all the details that are necessary to differentiate between the two closely related tree species which may blur some of the sitespecific sensitivity of the two oak species to climate change. This may positively affect the change in productivity we simulated if a species-specific oak parameterization represents oak trees better adapted to specific local conditions. However, this may also negatively simulated productivity changes if the current, generic oak parameterization actually represents a broad ecological niche that allows the generic oaks to withstand a larger range of adverse climate change effects than the narrower, species-specific parameterization. These two aspects regarding the species parameters of $4 \mathrm{C}$ highlight the potential for model improvement in terms of refining the species parameters.

\subsection{Climate change scenario uncertainties}

One important element of this study was to highlight important uncertainties of the projections of climate change impacts on forest productivity that arise from the climate models used to drive forest models. Thus, the application of several climate change scenarios from different climate models, of different realizations of the same model as well as the use of different $\mathrm{CO}_{2}$ emission scenarios is a crucial component of our assessment since the variation in between climate models has been found to be higher than in between different $\mathrm{CO}_{2}$ emission scenarios driving one climate model (e.g. Buisson et al. 2010). Our results confirm the findings of Morales et al. (2007) that the effects of using different climate models are more important than the choice of the $\mathrm{CO}_{2}$ emission scenario, hence that the effect of inter-model variation of the climate models is large. Our results also show that different realizations of the same emission scenario and the same GCM/RCM combination (in this case, CCLM/ECHAM5) can lead to responses of forest productivity that may be stronger than the difference between emission scenarios, hence that the effect of intramodel variation of the climate models is large. This is because the different realizations differ more in the projected climate change than the different emission scenarios, especially for the coming decades (Table 2), where the difference in between $\left[\mathrm{CO}_{2}\right]$ which is driving climate change is not that big in the emission scenarios. These results emphasizes the importance to rely on scenarios of several climate models and different realizations of the same scenario if available to provide a more complete picture of plausible future changes in forest productivity. However, it would also be crucial to include more drastic climate change scenarios following the newly developed RCP 8.5 (Moss et al. 2010) since thus far $\mathrm{CO}_{2}$ emissions seem to continue unabated (Monastersky 2013).

\subsection{Persistence of $\mathrm{CO}_{2}$ effects}

While we did not consider model parameter uncertainty in this study, we stress one crucial element of model structural uncertainty throughout our study: the effect of $\mathrm{CO}_{2}$. Persistent $\mathrm{CO}_{2}$ effects enhance productivity through $\mathrm{CO}_{2}$ fertilization and increasing water-use efficiency (Körner 2006). In 4C, the $\mathrm{CO}_{2}$ effects on photosynthesis are modelled according to a modified version of Haxeltine and Prentice's (1996) photosynthesis model which captures the direct effects of $\mathrm{CO}_{2}$ on photosynthesis at the leaf level and the indirect effects on stomatal conductance and water-use efficiency. There is however uncertainty about the long-term persistence of these effects depending on several factors such as site quality, forest development stage and interactions with nitrogen deposition and their implications for forest growth at the forest stand scale (Körner et al. 2005; Körner 2006; Huang et al. 2007; Hyvönen et al. 2007; Norby et al. 2010; Peñuelas et al. 2011). For the twentieth century, using a similar modeling approach Bellassen et al. (2011) find a very strong importance of $\left[\mathrm{CO}_{2}\right]$ as driver of increasing forest productivity followed by climate, while the forest age structure contributed only to a much smaller extent. Keenan et al. (2011) also found strong 
differences between driving a PBM with persistent $\mathrm{CO}_{2}$ effects or an acclimation of photosynthesis to $\left[\mathrm{CO}_{2}\right]$. This pattern is also obvious for the forests stands in our model simulations. Negative effects of climate change on productivity are almost entirely overruled under persistent $\mathrm{CO}_{2}$ effects. This leads to an increasing divergence of productivity changes throughout the twenty-first century: Under persistent $\mathrm{CO}_{2}$ effects, productivity increases more towards the end of the century, while under an acclimation of photosynthesis to $\left[\mathrm{CO}_{2}\right]$, productivity decreases more towards the end of the century (see also Figs. $14,15,16,17,18$, and 19 in the ESM). This pattern is consistent throughout most of Europe, besides at some sites in Southern Europe with strongly decreasing precipitation. For these sites, decreasing productivity under climate change is likely. Furthermore, the $\mathrm{CO}_{2}$ effects level out geographic differences in NPP changes, an effect also emphasized by Bellassen et al. (2011) who highlight the homogenous effect of $\left[\mathrm{CO}_{2}\right]$ on NPP across Europe as opposed to local climatic trends. To conclude, it is important to note that there is no fully accepted mechanistic formulation of how to model the effects of $\left[\mathrm{CO}_{2}\right]$ in PBMs that provide results from the leaf to the stand level. Acclimation of physiological processes to elevated $\left[\mathrm{CO}_{2}\right]$ and temperature and nutrient limitation (Lukac et al. 2010) may dampen the strong effects simulated with $4 \mathrm{C}$. In $4 \mathrm{C}$, nitrogen is not allocated within the plants and hence effects of elevated $\left[\mathrm{CO}_{2}\right]$ on leaf nitrogen content are not covered. The nitrogen cycle is not closed so that leaves modelled with $4 \mathrm{C}$ have a constant nitrogen content. Thus, potential feedbacks of elevated $\left[\mathrm{CO}_{2}\right]$ and stand development leading to decreasing leaf nitrogen content (Norby et al. 2010) are not covered by 4C. Since leaves decompose more rapidly than other organs in $4 \mathrm{C}$, a change in allocation of nitrogen could induce limitations of $\mathrm{CO}_{2}$ effects as observed in experiments (Norby et al. 2010). Effects of elevated $\left[\mathrm{CO}_{2}\right]$ on the allocation of NPP are also not covered by $4 \mathrm{C}$ although these may feedback on photosynthesis in reality (Hyvönen et al. 2007). Moreover, $\left[\mathrm{CO}_{2}\right]$-induced higher growth rates are associated with shorter life spans of trees (Bugmann and Bigler 2011; di Filippo et al. 2012) an effect not accounted for in $4 \mathrm{C}$. Therefore, we present the range of results from our simulations using an acclimation of photosynthesis to $\left[\mathrm{CO}_{2}\right]$ and persistent $\mathrm{CO}_{2}$ effects as a range of possible developments of forest productivity. Of course, simply keeping $\left[\mathrm{CO}_{2}\right]$ constant as we assumed in our simulations, featuring an acclimation of photosynthesis to $\left[\mathrm{CO}_{2}\right]$ does not fully account for the processes involved in acclimation and downregulation of photosynthesis but it is a useful model assumption to integrate concerns about the long-term persistence of $\mathrm{CO}_{2}$ effects on productivity.

\subsection{Effects not included in this study}

There are also other effects on forest productivity that have not been considered in this study. We did not include the effects of nitrogen deposition on forest productivity since although having been important in the past (de Vries et al. 2006; Solberg et al. 2009), the future role of nitrogen depositions is debated (Churkina et al. 2007; Kahle et al. 2008; Reay et al. 2008). Including different assumptions about future nitrogen deposition similarly to the assumptions about $\left[\mathrm{CO}_{2}\right]$ included in this study would be interesting for future assessments of changing forest productivity. Also, we did not consider age-class effects and long-term forest development including regeneration and succession in our simulations but rather focused on 30-year time slices starting always with the same stand and soil conditions. This is because we suppose that the Level-II stands used here are typical for European conditions and that similar stands will exist for the next decades although not at exactly the same location. It is however important to note that this approach does not account for long-term changes such as changes in soil conditions that are in turn affected by climate change. Furthermore, this approach also precludes that our standlevel results maybe interpreted as concrete temporally explicit predictions of the forest state at each specific site, since the productivity change at each Level-II plot due to climate change will occur in concert with developmental and management changes which are not covered by our time-slice approach. We also did not include effects of ozone or of changing diffuse to direct light ratio on forest productivity since such effects are currently not implemented in 4C. Furthermore, challenges arise from applying $4 \mathrm{C}$ across Europe since the species-specific parameters of $4 \mathrm{C}$ (e.g. those influencing carbon allocation) are fixed in this study although in reality they vary across Europe (Reyer et al., in preparation). Ultimately, it is important to note that this study only considers physiological effects of climate change and $\left[\mathrm{CO}_{2}\right]$ and does not include changing management practices or disturbances which are however likely to be affected by climate change and socioeconomic developments.

\subsection{Implications for carbon cycling and forest management}

Ultimately our results are relevant for a better assessment of both the European carbon cycle and forest management under changing environmental conditions. Although a majority of the climate change scenarios and assumptions about the persistence of $\mathrm{CO}_{2}$ effects used here may not entail farreaching changes in forest productivity, our results show that some scenarios may lead to decreasing or increasing productivity and subsequent alterations of the carbon uptake of Europe's forests. This may strongly impact the mitigation potential but also the provision of timber and other ecosystem services of Europe's forests. Forest managers have to cope with this uncertainty and possibly adapt forest management planning by incorporating risk-spreading and adaptive management approaches. 
Acknowledgments This paper is dedicated to Matthias Dobbertin. We are grateful to ICP Forests and in particular Richard Fischer, Matthias Dobbertin, and Oliver Granke for helping us in all aspects concerning the Level-II database. This study was based on data that are part of the UNECE ICP Forests Collaborative Database (see www.icp-forests.org). In particular, data from the following countries and institutions were used: Austria (Bundesforschungs- und Ausbildungszentrum für Wald, Naturgefahren und Landschaft, Wien. Mr. Ferdinand Kristöfel (ferdinand.kristoefel@ bfw.gv.at); Belgium (Research Institute for Nature and Forest, Ministère de la Région Wallonne and Mathieu Jonard in particular); Czech Republic (Forestry and Game Management Research Institute, VULHM); Estonia (Estonian Environment Information Centre); Finland (Finnish Forest Research Institute, METLA); France (Ministère de l'agriculture et de la pêche) ; Germany (Forstliche Versuchs- und Forschungsanstalt BadenWürttemberg, Bayerische Landesanstalt für Wald und Forstwirtschaft, Landesforstanstalt Eberswalde, Nordwestdeutsche Forstliche Versuchsanstalt, Ministerium für Landwirtschaft, Umwelt und Verbraucherschutz Schwerin, Landesamt für Natur, Umwelt und Verbraucherschutz NRW, Forschungsanstalt für Waldökologie und Forstwirtschaft Rheinland-Pfalz, Ministerium für Umwelt, Energie und Verkehr, Landesamt für Umwelt- und Arbeitsschutz Saarbrücken, Staatsbetrieb Sachsenforst, Thüringer Landesanstalt für Wald, Jagd u. Fischerei); Hungary (State Forest Service); Italy (Corpo Forestale dello Stato-Servizio CONECOFOR); Lithuania (State Forest Survey Service); The Netherlands (Ministry of Agriculture, Nature and Food Quality); Norway (Norwegian Forest and Landscape Institute); Poland (Forest Research Institute); Romania (Forest Research and Management Institute, ICAS); Slovak Republic (National Forest Centre); Spain (Forest Health Unit (SPCAN)/DG Nature and Forest Policy (DGMNyPF)/ Ministerio de Medio Ambiente, y Medio Rural y Marino); Sweden (Swedish Forest Agency); Switzerland (Eidgenössische Forschungsanstalt für Wald, Schnee und Landschaft, WSL). Data collection and evaluations were co-financed under the LIFE+Regulation (EC) 614/2007 of the European Parliament and of the Council. We also would like to thank Beate Klöcking providing us data for the validation. We greatly acknowledge the provision of the CRUPIK dataset by Peter Werner and Herman Österle, the NORDFLUX data by Pasi Kolari and the many people contributing to the Euroflux/ CarboEurope database, in particular D. Papale, R. Valentini, A. Granier, I. Janssens, B. Gielen and R. Ceulemans. Furthermore, Niklaus Zimmermann, Pedro Contro, Michael Benken, Julia Marusczyk and Alexandra Wilke greatly supported the data preparation for the 4C application. We thank Marc Metzger and Marcus Lindner for providing us the environmental zones of Europe data. The ENSEMBLES data used in this work was funded by the EU FP6 Integrated Project ENSEMBLES (Contract No. 505539) whose support is gratefully acknowledged. We are grateful to the IT-services of the Potsdam Institute for Climate Impact Research for providing excellent computational infrastructure to carry out this study.

Funding All authors acknowledge funding from the EC FP7 MOTIVE project (grant agreement No. 226544).

\section{References}

Ainsworth EA, Long SP (2005) What have we learned from 15 years of free-air $\mathrm{CO}_{2}$ enrichment (FACE)? A meta-analytic review of the responses of photosynthesis, canopy properties and plant production to rising $\mathrm{CO}_{2}$. New Phytol 165:351-371

Ammer C, Albrecht L, Borchert H, Brosinger F, Dittmar C, Elling W, Ewald J, Felbermeier B, von Gilsa H, Huss J, Kenk G, Kölling C, Kohnle U, Meyer P, Mosandl R, Moosmayer H, Palmer S, Reif A, Rehfuess K, Stimm B (2005) Zur Zukunft der Buche (Fagus sylvatica L.) in Mitteleuropa. Allg Forst- und Jagdztg 176:60-67
Bellassen V, Viovy N, Luyssaert S, Le Maire G, Schelhaas M-J, Ciais P (2011) Reconstruction and attribution of the carbon sink of European forests between 1950 and 2000. Glob Chang Biol 17:3274-3292. doi:10.1111/j.1365-2486.2011.02476.x

BGR (2004) Nutzungsdifferenzierte Bodenübersichtskarte der Bundesrepublik Deutschland 1:100.000.000 (Wald-BÜK 1000). Bundesanstalt für Geowissenschaften und Rohstoffe, Hannover

Boisvenue C, Running SW (2006) Impacts of climate change on natural forest productivity - evidence since the middle of the 20th century. Glob Chang Biol 12:862-882

Bontemps JD, Hervé JC, Duplat P, Dhôte JF (2012) Shifts in the heightrelated competitiveness of tree species following recent climate warming and implications for tree community composition: the case of common beech and sessile oak as predominant broadleaved species in Europe. Oikos 121:1287-1299

Bugmann $\mathrm{H}$, Bigler C (2011) Will the $\mathrm{CO}_{2}$ fertilization effect in forests be offset by reduced tree longevity? Oecologia 165:533-544. doi:10.1007/s00442-010-1837-4

Bugmann H, Grote R, Lasch P, Lindner M, Suckow F (1997) A new forest gap model to study the effects of environmental change on forest structure and functioning. In: Mohren GMJ, Kramer K, Sabate S (eds) Impacts of Global Change of Tree Physiology and Forest Ecosystem. Proceedings of the International Conference on Impacts of Global Change on Tree Physiology and Forest Ecosystems, held 26-29 November 1996, Wageningen. Forestry Science. Kluwer Academic Publisher, Dordrecht, pp 255-261

Bugmann H, Palahi M, Bontemps JD, Tomé M (2010) Trends in modeling to address forest management and environmental challenges in Europe. For. Sys. 19(SI):3-7

Buisson L, Thuiller W, Casajus N, Lek S, Grenouillet G (2010) Uncertainty in ensemble forecasting of species distribution. Glob Chang Biol 16:1145-1157

Chmura DJ, Anderson PD, Howe GT, Harrington CA, Halofsky JE, Peterson DL, Shaw DC, Brad St.Clair J (2011) Forest responses to climate change in the northwestern United States: ecophysiological foundations for adaptive management. For Ecol Manage 261:1121-1142

Churkina G, Trusilova K, Vetter M, Dentener F (2007) Contributions of nitrogen deposition and forest regrowth to terrestrial carbon uptake. Carbon Balance Manag 2:5

Déqué M, Rowell D, Lüthi D, Giorgi F, Christensen J, Rockel B, Jacob D, Kjellström E, de Castro M, van den Hurk B (2007) An intercomparison of regional climate simulations for Europe: assessing uncertainties in model projections. Clim Chang 81:53-70

de Vries W, Gert Jan R, Per G, Hubert S (2006) The impact of nitrogen deposition on carbon sequestration in European forests and forest soils. Glob Change Biol 12:1151-1173

de Vries W, Vel E, Reinds GJ, Deelstra H, Klap JM, Leeters EEJM, Hendriks CMA, Kerkvoorden M, Landmann G, Herkendell J, Haussmann T, Erisman JW (2003) Intensive monitoring of forest ecosystems in Europe: 1. Objectives, set-up and evaluation strategy. For Ecol Manag 174:77-95

Deutsch C, Journel A (1992) GSLIB: Geostatistical Software Library and User's Guide. Oxford University Press, New York

Di Filippo A, Biondi F, Maugeri M, Schirone B, Piovesan G (2012) Bioclimate and growth history affect beech lifespan in the Italian Alps and Apennines. Glob Chang Biol 18:960-972. doi:10.1111/ j.1365-2486.2011.02617.x

Eggers J, Lindner M, Zudin S, Zaehle S, Lisk J (2008) Impact of changing wood demand, climate and land use on European forest resources and carbon stocks during the 21 st century. Glob Chang Biol 14:2288-2303. doi:10.1111/j.13652486.2008.01653.x

ESBN, EC (2004) European Soil Database (v 2.0). European Soil Bureau Network and the European Commission, EUR 19945 EN, March 2004 
Fontes L, Bontemps JD, Bugmann H, van Oijen M, Gracia CA, Kramer K, Lindner M, Rötzer T, Skovsgaard JP (2010) Models supporting forest management in a changing environment. For. Sys. 19(SI):8-29

Fuchs T (2008) GPCC Annual report for year 2008. Development of the GPCC data base and analysis products. GPCC, Offenbach, Germany

Galiano L, Martínez-Vilalta J, Lloret F (2010) Drought-induced multifactor decline of Scots pine in the pyrenees and potential vegetation change by the expansion of co-occurring oak species. Ecosyst 13:978-991. doi:10.1007/s10021-010-9368-8

Geßler A, Keitel C, Kreuzwieser J, Matyssek R, Seiler W, Rennenberg H (2007) Potential risks for European beech (Fagus sylvatica L.) in a changing climate. Trees - Struct. and. Funct 21:1-11

Haxeltine A, Prentice IC (1996) A general model for the light-use efficiency of primary production. Funct Ecol 10:551-561

Hollweg H-D, Böhm B, Fast I, Hennemuth B, Keuler K, Keup-Thiel E, Lautenschlager M, Legutke S, Radtke K, Rockel B, Schubert M, Will A, Woldt M, Wunram C (2008) Ensemble Simulations over Europe with the Regional Climate Model CLM forced with IPCC AR4 Global Scenarios. Max-Planck-Institute for Meteorology, Hamburg, Germany

Huang J, Bergeron Y, Denneler B, Berninger F, Tardif J (2007) Response of forest trees to increased atmospheric $\mathrm{CO}_{2}$. Crit Rev Plant Sci 26:265-283

Hyvönen R, Ågren GI, Linder S, Persson T, Cotrufo MF, Ekblad A, Freeman M, Grelle A, Janssens IA, Jarvis PG, Kellomäki S, Lindroth A, Loustau D, Lundmark T, Norby RJ, Oren R, Pilegaard K, Ryan MG, Sigurdsson BD, Strömgren M, Van Oijen M, Wallin G (2007) The likely impact of elevated $\left[\mathrm{CO}_{2}\right]$, nitrogen deposition, increased temperature and management on carbon sequestration in temperate and boreal forest ecosystems: a literature review. New Phytol 173:463-480

Jump AS, Hunt JM, Penuelas J (2006) Rapid climate change-related growth decline at the southern range edge of Fagus sylvatica. Glob Chang Biol 12:2163-2174

Kahle H-P, Karjalainen T, Schuck A, Agren GI, Kellomäki S, Mellert K, Prietzel J, Rehfuess K-E, Spiecker H (eds) (2008) Causes and consequences of forest growth trends in Europe. Brill, Leiden

Kauppi PE, Mielikainen K, Kuusela K (1992) Biomass and carbon budget of European forests, 1971 to 1990. Sci 256:70-74

Keenan T, Maria Serra J, Lloret F, Ninyerola M, Sabate S (2011) Predicting the future of forests in the Mediterranean under climate change, with niche- and process-based models: $\mathrm{CO}_{2}$ matters! Glob Chang Biol 17:565-579. doi:10.1111/j.1365-2486.2010.02254.x

Kellomäki S, Leinonen SE (2005) Management of European Forests under Changing Climatic Conditions. Final Report of the Project "Silvicultural Response Strategies to Climatic Change in Management of European Forests" funded by the European Union under the Contract EVK2-2000-00723 (SilviStrat). Research Notes. University of Joensuu, Faculty of Forestry, Joensuu

Kint V, Aertsen W, Campioli M, Vansteenkiste D, Delcloo A, Muys B (2012) Radial growth change of temperate tree species in response to altered regional climate and air quality in the period 1901-2008. Clim Change 115:343-363

Kölling C, Knoke T, Schall P, Ammer C (2009) Überlegungen zum Risiko des Fichtenanbaus in Deutschland vor dem Hintergrund des Klimawandels. Forstarch 80:42-54

Körner C (2006) Plant $\mathrm{CO}_{2}$ responses: an issue of definition, time and resource supply. New Phytol 172:393-411

Körner C, Asshoff R, Bignucolo O, Hattenschwiler S, Keel SG, PelaezRiedl S, Pepin S, Siegwolf RTW, Zotz G (2005) Carbon flux and growth in mature deciduous forest trees exposed to elevated $\mathrm{CO}_{2}$. Sci 309:1360-1362. doi:10.1126/science.1113977

Landsberg J (2003) Modelling forest ecosystems: state of the art, challenges, and future directions. Can J For Res 33:385-397
Lasch P, Badeck FW, Suckow F, Lindner M, Mohr P (2005) Modelbased analysis of management alternatives at stand and regional level in Brandenburg (Germany). For Ecol Manage 207:59-74

Lautenschläger M, Keuler K, Wunram C, Keup-Thiel E, Schubert M, Will A, Rockel B, Boehm U (2009a) Climate Simulation with CLM, Climate of the 20th Century run no.1, Data Stream 3: European region MPI-M/MaD. World Data Center for Climate. doi:10.1594/WDCC/CLM_C20_1_D3

Lautenschläger M, Keuler K, Wunram C, Keup-Thiel E, Schubert M, Will A, Rockel B, Boehm U (2009b) Climate Simulation with CLM, Climate of the 20th Century run no.2, Data Stream 3: European region MPI-M/MaD. World Data Center for Climate. doi:10.1594/WDCC/CLM C20 2 D3

Lautenschläger M, Keuler K, Wunram C, Keup-Thiel E, Schubert M, Will A, Rockel B, Boehm U (2009c) Climate Simulation with CLM, Scenario A1B run no.1, Data Stream 3: European region MPI-M/MaD. World Data Center for Climate. doi:10.1594/ WDCC/CLM_A1B_1_D3

Lautenschläger M, Keuler K, Wunram C, Keup-Thiel E, Schubert M, Will A, Rockel B, Boehm U (2009d) Climate Simulation with CLM, Scenario A1B run no.2, Data Stream 3: European region MPI-M/MaD. World Data Center for Climate. doi:10.1594/ WDCC/CLM A1B 2 D3

Lautenschläger M, Keuler $\overline{\mathrm{K}}$, Wunram C, Keup-Thiel E, Schubert M, Will A, Rockel B, Boehm U (2009e) Climate simulation with CLM, Scenario B1 run no.1, Data Stream 3: European region MPI-M/MaD. World Data Center for Climate. doi:10.1594/ WDCC/CLM_B1_1_D3

Lautenschläger M, Keuler K, Wunram C, Keup-Thiel E, Schubert M, Will A, Rockel B, Boehm U (2009f) Climate Simulation with CLM, Scenario B1 run no.2, Data Stream 3: European region MPI-M/MaD. World Data Center for Climate. doi:10.1594/ WDCC/CLM_B1_2_D3

Lukac M, Calfapietra C, Lagomarsino A, Loreto F (2010) Global climate change and tree nutrition: effects of elevated $\mathrm{CO}_{2}$ and temperature. Tree Physiol 30:1209-1220. doi:10.1093/treephys/tpq040

Medlyn BE, Duursma RA, Zeppel MJB (2011) Forest productivity under climate change: a checklist for evaluating model studies. Wiley Interdiscip Rev Clim Chang 2:332-355

Metzger MJ, Bunce RGH, Jongman RHG, Mücher CA, Watkins JW (2005) A climatic stratification of the environment of Europe. Glob Ecol Biogeogr 14:549-563. doi:10.1111/j.1466-822X.2005.00190.x

Milne R, Van Oijen M (2005) A comparison of two modelling studies of environmental effects on forest carbon stocks across Europe. Ann of For Sci 62:911-923. doi:10.1051/forest:2005082

Mitchell TD, Jones PD (2005) An improved method of constructing a database of monthly climate observations and associated highresolution grids. Int J Climatol 25:693-712. doi:10.1002/joc.1181

Monastersky R (2013) Global carbon dioxide levels near worrisome milestone. Nat 497:13-14

Morales P, Hickler T, Rowell DP, Smith B, Sykes MT (2007) Changes in European ecosystem productivity and carbon balance driven by regional climate model output. Glob Chang Biol 13:108-122. doi:10.1111/j.1365-2486.2006.01289.x

Moss RH, Edmonds JA, Hibbard KA, Manning MR, Rose SK, van Vuuren DP, Carter TR, Emori S, Kainuma M, Kram T, Meehl GA, Mitchell JFB, Nakicenovic N, Riahi K, Smith SJ, Stouffer RJ, Thomson AM, Weyant JP, Wilbanks TJ (2010) The next generation of scenarios for climate change research and assessment. Nat 463:747-756

Myneni RB, Keeling CD, Tucker CJ, Asrar G, Nemani R (1997) Increased plant growth in the northern high latitudes from 1981 to 1991. Nat 386:698-702

Nakicenovic N, Alcamo J, Davis G, Bd V, Fenhann J, Gaffin S, Gregory K, Grübler A, Jung T, Kram T, Rovere EL, Michaelis L, Mori S, Morita T, Pepper W, Pitcher H, Price L, Riahi K, Roehrl A, Rogner 
H, Sankovski A, Schlesinger M, Shukla P, Smith S, Swart R, Sv R, Victor N, Dadi Z (2000) IPCC special report emission scenarios. Cambridge University Press, Cambridge

Nemani RR, Keeling CD, Hashimoto H, Jolly WM, Piper SC, Tucker CJ, Myneni RB, Running SW (2003) Climate-driven increases in global terrestrial net primary production from 1982 to 1999. Sci 300:1560-1563. doi:10.1126/science. 1082750

New M, Hulme M, Jones P (2000) Representing Twentieth-century space-time climate variability. Part II: development of 1901-96 monthly grids of terrestrial surface climate. J of Clim 13:22172238. doi:10.1175/1520-0442(2000)0132217:RTCSTC $>2.0 . C O ; 2$

New M, Hulme M, Jones PD (1999) Representing twentieth century space-time climate variability. Part 1: development of a 1961-90 mean monthly terrestrial climatology. J of Clim 12:829-856

Norby RJ, Warren JM, Iversen CM, Medlyn BE, McMurtrie RE (2010) $\mathrm{CO}_{2}$ enhancement of forest productivity constrained by limited nitrogen availability. Proc Natl Acad Sci 107:19368-19373. doi:10.1073/pnas.1006463107

Österle H, Gerstengarbe F-W, Werner PC (2003) Homogenisierung und Aktualisierung des Klimadatensatzes der Climate Research Unit der University of East Anglia, Norwich. Terra Nostra 6:326-329

Peñuelas J, Canadell JG, Ogaya R (2011) Increased water-use efficiency during the 20th century did not translate into enhanced tree growth. Glob Ecol Biogeogr 20:597-608

Pinkard EA, Battaglia M, Bruce J, Leriche A, Kriticos DJ (2010) Process-based modelling of the severity and impact of foliar pest attack on eucalypt plantation productivity under current and future climates. For Ecol Manag 259:839-847

Piovesan G, Biondi F, Filippo AD, Alessandrini A, Maugeri M (2008) Drought-driven growth reduction in old beech (Fagus sylvatica L.) forests of the central Apennines, Italy. Glob Chang Biol 14:1265-1281

Reay DS, Dentener F, Smith P, Grace J, Feely RA (2008) Global nitrogen deposition and carbon sinks. Nat Geosci 1:430-437

Rebetez M, Dobbertin M (2004) Climate change may already threaten Scots pine stands in the Swiss Alps. Theor Appl Climatol 79:1-9. doi:10.1007/s00704-004-0058-3

Reich PB, Oleksyn J (2008) Climate warming will reduce growth and survival of Scots pine except in the far north. Ecol Lett 11:588 597. doi:10.1111/j.1461-0248.2008.01172.x

Reyer C, Lasch P, Mohren GMJ, Sterck FJ (2010) Inter-specific competition in mixed forests of Douglas-fir (Pseudotsuga menziesii) and common beech (Fagus sylvatica) under climate change-a model-based analysis. Ann of For Sci 67:805

Reyer C, Gutsch M, Lasch P (2012) Simulated forest productivity and biomass changes under global change in Europe. In: Pötzelsberger E, Mäkelä A, Mohren GMJ, Palahí M, Tomé M, Hasenauer H (eds) Modelling Forest Ecosystems - Concepts, Data and
Application. Proceedings of the COST FP0603 Spring School, held in Kaprun, Austria, May 9th-13th, 2011. Institute of Silviculture, BOKU, Vienna. ISBN: 978-3-900962-98-2, pp 151-158

Rudolf B, Becker A, Schneider U, Meyer-Christoffer A, Ziese M (2010) GPCC Status Report,Global Precipitation Climatology Centre. Offenbach, Germany

Rudolf B, Scheider U (2005) Calculation of gridded precipitation data fort he global land-surface using in-situ gauge observations. Proc. 2nd Workshop Int. Prec. Work. Gp.

Scheider U, Fuchs T, Meyer-Christoffer A, Rudolf B (2008) Global precipitation analysis products of the GPCC. Global Precipitation Climatology Centre, Offenbach, Germany

Seidl R, Fernandes PM, Fonseca TF, Gillet F, Jönsson AM, Merganicová K, Netherer S, Arpaci A, Bontemps J-D, Bugmann H, González-Olabarria JR, Lasch P, Meredieu C, Moreira F, Schelhaas M-J, Mohren F (2011) Modelling natural disturbances in forest ecosystems: a review. Ecol Model 222:903-924

Solberg S, Dobbertin M, Reinds GJ, Lange H, Andreassen K, Fernandez PG, Hildingsson A, de Vries W (2009) Analyses of the impact of changes in atmospheric deposition and climate on forest growth in European monitoring plots: a stand growth approach. For Ecol Manag 258:1735-1750

Spiecker H, Mielikäinen K, Köhl M, Skovsgaard JP (eds) (1996) Growth trends in European forests. Springer, Berlin

Tans P, Keeling R (2012) Trends in Atmospheric Carbon Dioxide. NOAA/ESRL (www.esrl.noaa.gov/gmd/ccgg/trends/) and Scripps Institution of Oceanography (scrippsco2.ucsd.edu/),

USGS (2004) Shuttle Radar Topography Mission, 30 Arc Second scenes (SRTM_GTOPO_u30_n040e020, SRTM_GTOPO_u30_n090e020, SRTM_GTOPO_u30_n090e060, SRTM_GTOPO_u30 n040w020, SRTM_GTOPO_u30_n090w020, SRTM_GTOPO_u30 n040w060, SRTM_GTOPO_u30_n090w060), Unfilled, Unfinished 2.0, Global Land Cover Facility, University of Maryland, Maryland, USA

van der Linden P, Mitchell J (eds) (2009) ENSEMBLES: climate change and its impacts: summary of research and results from the ENSEMBLES project. Met Office Hadley Centre, Exeter, UK

Vayreda J, Martinez-Vilalta J, Gracia M, Retana J (2012) Recent climate changes interact with stand structure and management to determine changes in tree carbon stocks in Spanish forests. Glob Chang Biol 18:1028-1041

Wamelink GWW, Wieggers HJJ, Reinds GJ, Kros J, Mol-Dijkstra JP, van Oijen M, de Vries W (2009) Modelling impacts of changes in carbon dioxide concentration, climate and nitrogen deposition on carbon sequestration by European forests and forest soils. For Ecol Manag 258:1794-1805 